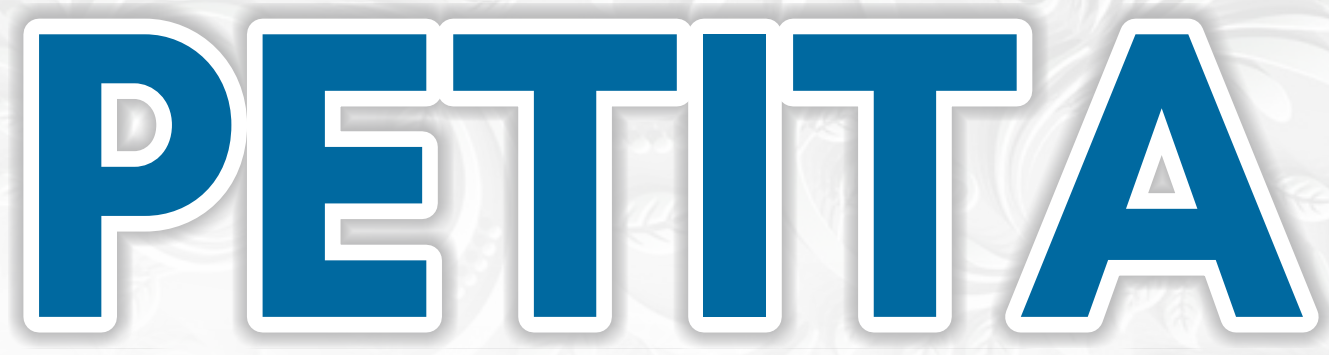

Jurnal Kajian Ilmu Hukum dan Syariah

Published By:

Lembaga Kajian Konstitusi Indonesia (LKKI)

Fakultas Syariah dan Hukum Universitas Islam Negeri (UIN) Ar-Raniry Banda Aceh Jl. Syeikh Abdul Rauf, Kopelma Darussalam Banda Aceh, Telp: 0651-7557442 Website: http://petita.ar-raniry.ac.id 


\section{Contents}

TES DNA SEBAGAI ALAT BUKTI PENGGANTI EMPAT ORANG SAKSI (ANALISIS QANUN ACEH NOMOR 6 TAHUN 2014 TENTANG HUKUM JINAYAH)

(Era Fadli, Mursyid Djawas \& Syarifah Rahmatillah / 1-9)

SISTEM JAMINAN KESELAMATAN KERJA KARYAWAN BENGKEL LAS MENURUT PERSPEKTIF HUKUM ISLAM DAN UNDANG-UNDANG NO.13 TAHUN 2003 TENTANG KETENAGAKERJAAN (Studi Kasus Kecamatan Tanah Jambo Aye)

(Lilis Diatana, Edi Darmawijaya \& Faisal Fauzan / 10-23)

PERTANGGUNGAN RISIKO TERHADAP SEJUMLAH MINYAK YANG SUSUT DALAM MASA PENGANGKUTAN (Studi Kasus pada PT.Citra Bintang Familindo)

(Mayliza / 24-35)

KEDUDUKAN MEMORANDUMOF UNDERSTANDING (MOU) HELSINKI DALAM PEMBENTUKAN UNDANG- UNDANG NOMOR 11 TAHUN 2006 TENTANG PEMERINTAHAN ACEH

(Qonita Royani Salpina, Rusjdi Ali Muhammad \& Yenny Sriwahyuni / 36-46)

PELELANGAN OBJEK JAMINAN MURABAHAH PADA BANK SYARIAH MANDIRI CABANG BANDA ACEH MELALUI KANTOR PELELANGAN KEKAYAAN NEGARA DAN LELANG DALAM PERSPEKTIF BAI' AL-MUZAYYADAH

(Reza Fahmi / 47-63)

PENERAPAN SANKSI TINDAK PIDANA ILLEGAL LOGGING DI KAWASAN HUTAN LINDUNG DITINJAU DARI DARI UU NO. 18 TAHUN 2013 TENTANG PENCEGAHAN DAN PEMBERANTASAN PERUSAKAN HUTAN (Studi Kasus Kecamatan Bener Kelipah Kabupaten Bener Meriah)

(Ali Abu Bakar, Mizaj Iskandar \& Reza Maulana / 64-74)

EFEKTIVITAS PELAKSANAAN SANKSI TALAK DI LUAR MAHKAMAH RENDAH SYARIAH (STUDI KASUS DI MAHKAMAH RENDAH SYARIAH SELANGOR, MALAYSIA)

(Rukiah M. Ali \& Siti Maimunah Binti Mohd Rijal / 75-95)

SISTEM PERLINDUNGAN PEMKAB ACEH BESAR TERHADAP PERTAMBANGAN BATUAN DALAM PERSPEKTIF MILK AL-DAULAH (PENELITIAN PADA TAMBANG BATUAN DI KECAMATAN INDRAPURI)

(Siti Rohaya / 96-103) 
PETITA: Jurnal Kajian Ilmu Hukum dan Syariah

Volume 3, Number 1, 2018

P-ISSN: 2502-8006 E-ISSN: 2549-8274

DOI: https://doi.org/10.22373/petita.v3i1.37

\title{
PENERAPAN SANKSI TINDAK PIDANA ILLEGAL LOGGING DI KAWASAN HUTAN LINDUNG DITINJAU DARI DARI UU NO. 18 TAHUN 2013 TENTANG PENCEGAHAN DAN PEMBERANTASAN PERUSAKAN HUTAN ( Studi Kasus Kecamatan Bener Kelipah Kabupaten Bener Meriah )
}

\author{
Ali Abu Bakar, Mizaj Iskandar \&Reza Maulana \\ Ilmu Hukum, Fakulktas Syari'ah dan Hukum UIN Ar-raniry \\ Email: aliabubakar@ar-raniry.ac.id
}

\begin{abstract}
Paya Rebol protected forest serves as the buffer system of water springs source for the communities in several sub-districts around the forest, such as Bener Kelipah, Bandar and Syah main sub-districts. Unfortunately, illegal activity of converting the protected forest to horticultural agriculture (plant cultivation) still occurs to date. The research used was a descriptive-analytical method with an empirical juridical approach, aimed to examine the law in the real sense and investigate how the law performs in the community. The results showed that supervision conducted by the Aceh Department of Environment and Forestry has not been effective. Hence, illegal logging still occurs due to the economic needs, the lack of forest supervisory personnel, the customs of indigenous peoples, and the unclear boundaries of forest areas. Suggestions for the related authorities are to combine and maximize the preventive and repressive efforts, and early detection, to suppress the cases of encroachment and destruction in the Paya Rebol protected forest area.
\end{abstract}

Keywords: Criminal Act, Illegal Loging, Forest Protection

Abstrak: Hutan lindung Paya Rebol merupakan kawasan hutan yang menjadi sistem penyangga sumber mata air bagi masyarakat di beberapa kecamatan yang berada di sekitar kawasan hutan, seperti kecamatan Bener Kelipah, Bandar dan Syah utama, kegiatan perambahan dan pengrusakan hutan (illegal logging) dengan merubah dan mengalihfungsikan hutan lindung menjadi lahan pertanian hortikultura (budidaya tanaman) secara tidak sah, sampai saat ini masih marak terjadi di kawasan hutan lindung Paya Rebol walaupun sebelumnya Dinas lingkungan Hidup dan kehutanan Aceh bekerja sama dengan pihak kepolisian telah menindak lanjuti kasus perambahan di hutan lindung tersebut, yang terbukti melanggar ketentuan Undang-undang Nomor 18 Tahun 2013 tentang Pencegahan dan Pemberantasan Perusakan Hutan.Yang menjadi fokus permasalahan adalah apa faktor penyebab, masih maraknya kegiatan illegal logging yang mengalih fungsikan hutan lindung, bagaimana modus operandi dan vevendi terjadinya kegiatan illegal logging, bagaimana sistem penerapan sanksi tindak pidana illegal logging yang terjadi di kawasan hutan lindung Paya Rebol, bagaimanakah upaya pencegahan dan penanggulangan terjadinya tindak pidana illegal logging di kawasan hutan lindung Paya Rebol. Metode penelitian yang digunakan adalah Metode Diskriptif analitis dengan pendekatan Yuridis empiris, yang bertujuan untuk melihat hukum dalam arti nyata dan meneliti bagaimana bekerjanya hukum dalam lingkungan masyarakat serta mengetahui bagaimana penerapan sanksi pidana terhadap kasus illegal logging tersebut. Hasil penelitian menujukan bahwa pengawasan yang dilakukan oleh Dinas lingkungan Hidup 
dan kehutanan Aceh belum efektif sehingga tindak pidana illegal logging masih terjadi yang disebabkan oleh kebutuhan ekonomi, kurangnya Personel aparat pengawas hutan, kebiasaan masyarakat adat, ketidak jelasan tapal batas kawasan hutan. Saran yang direkomendasikan hendakanya pihak pejabat terkait dapat mengkombinasikan dan memaksimalkan upaya-upaya preventif,upaya represif dan deteksi dini, yang diharapkan dapat terus menekan terjadinya kasus perambahan dan perusakan pada kawasan hutan lindung Paya Rebol.

\section{Kata kunci: Tindak pidana, Illegal logging, Hutan lindung, Paya Rebol}

\section{Pendahuluan}

Hutan sebagai salah satu karunia dan amanah Tuhan Yang Maha Esa, merupakan sumber daya alam yang memiliki aneka ragam kandungan dan kekayaan alam yang sangat bermanfaat dan berharga bagi manusia, ${ }^{1}$ baik manfaat ekologi (ilmu tentang struktur dan fungsi dari pada alam mencakup semua mahluk hidup). ${ }^{2}$ Sosial budaya, maupun ekonomi. Sebagai bentuk perwujudan rasa syukur terhadap karunianya maka hutan harus dijaga dan dimanfaatkan secara optimal dengan mempertimbangkan kecukupan luas daerah kawasan hutan dalam daerah aliran sungai, pulau atau provinsi serta keserasian manfaat secara froporsional sesuai sifat, karakteristik dan kerentanan perananya sebagai penyerasi keseimbangan lingkungan hidup dunia. ${ }^{3}$

Hutan merupakan sumber daya alam yang memiliki nilai yang strategis dalam pembangunan bangsa dan negara, keterlibatan negara dalam penataan dan pembinaan serta pengurusannya sangat dibutuhkan. Karena hal ini telah ditetapkan sebagaimana yang dimaksud dalam ketentuan Pasal 33 ayat (3) UUD 1945, bahwa bumi, air dan kekayaan alam yang terkandung di dalamnya dikuasai oleh Negara dan dipergunakan sebesar-besarnya untuk kesejahteran rakyat.

Penebangan liar atau tindak pidana illegal logging adalah praktik illegal terhadap kegiatan kehutanan yang berkaitan dengan pemanenan, pengelolaan serta penebangan dan perdagangan kayu yang tidak sesuai dengan hukum Indonesia atau kegiatan kehutanan yang belum mendapat izin dan merusak hutan. Seperti yang dimaksudkan dalam Pasal 1 Ayat (4), ayat (6) dan Ayat (10) Undang-undang Nomor 18 Tahun 2013 tentang Pencegahan dan Pemberantasan Perusakan Hutan, praktik ini tergolong dalam kejahatan teroganisir. ${ }^{4}$ Karena modusnya melibatkan cukong dan para petugas baik itu di tingkat pusat atau daerah dengan kata lain di balik kegiatan tersebut ada pihak oknum anggota aparatur negara dan sebagian instalansi pemerintah juga bermain di dalamnya. Di sisi lain penegakan hukum tindak pidana dIbidang kehutanan yang diatur dan dirumuskan dalam Undang-undang No. 18 Tahun 2013 tentang Pencegahan dan Pemberantasan Perusakan Hutan, tidak menyebutkan secara jelas apa yang dimaksudkan dengan illegal logging tersebut, dalam artian tidak dirumuskan secara limitatif (yang bersifat membatasi), sehingga banyak para praktisi hukum yang menafsirkan illegal logging sendiri-sendiri.

1 Esensi agama Islam dalam hal ini juga sangat condong kepada pelestarian lingkungan hidup. Kajian mendalam mengenai Islam dan ekologi sudah banyak dilakukan, diantaranya dapat merujuk Muhammad Harfin Zuhdi, 'Paradigma Fiqh Al-Bi'ah Berbasis Kecerdasan Naturalis: Tawaran Hukum Islam Terhadap Krisis Ekologi' [2017] AL-'ADALAH; Maghfur Ahmad, 'Ekologi Berbasis Syariah: Analisis Wacana Kritis Pemikiran Mudhofir Abdullah' (2015) 13 JURNAL HUKUM ISLAM 57 <http://e-journal.iainpekalongan.ac.id/index.php/jhi/article/view/496>; Dwi Runjani Juwita, 'Fiqh Lingkungan Hidup Dalam Perspektif Islam' [2017] El-Wasathuya: Jurnal Studi Agama.

2 Ninik Suparni, Pelestarian, Pengelolaan, Dan Penegakan Hukum Lingkungan (Sinar Grafika 1994), hlm. 1-5.

3 Ahmad Redi, Hukum Sumber Daya Alam Dalam Sektor Kehutanan (Sinar Grafika 2014), hlm. 170-171.

4 'Undang-Undang-Nomor 18 Tahun 2013' (Http://Www.Hukumonline.Com/Undang-Undang-Nomor 18 Tahun 2013/di akses tanggal 12 Maret 2017.11.23.) <http://www.hukumonline.com> accessed 12 March 2017. 
Berdasarkan data statistikyang dipublikasikan oleh DirektoratJendral Planologi Kehutanan dan Tata Lingkungan, Kementrian Lingkungan Hidup dan Kehutanan. Pada tahun 2015 saja Indonesia memiliki 29,7 juta ha, hutan lindung. 27,4 juta ha hutan konservasi. Hutan produksi terbatas 26,8 juta ha. Hutan produksi 29,3 juta ha. Total luas hutan di Indonesia sebanyak 128 juta ha. Yang tentunya setiap tahun terus mengalami penurunan. Dari total luas hutan tersebut indonesia menyisihkan 29.7 juta ha hutan lindung, yang merupakan kawasan hutan berdasarkan keadaan dan fisik wilayahnya, perlu dibina dan dipertahankan sebagian dengan penutupan vegetasi secara tetap, guna kepentingan hidrologi, yaitu mengatur tata air, mencegah bencana banjir dan erosi serta memelihara keawetan dan kesuburan tanah, baik dalam kawasan hutan yang bersangkutan maupun kawasan yang saling dipengaruhi sekitarnya. ${ }^{5}$

\section{Metode Penelitian}

Jenis Penelitian dalam penulisan karya ilmiah ini menggunakan metode Field Research atau penelitian Hukum Empiris adalah suatu metode penelitian hukum yang berfungsi untuk melihat hukum dalam arti nyata dan meneliti bagaimana bekerjanya hukum di lingkungan masyarakat. karena dalam penelitian ini meneliti orang dalam hubungan hidup di masyarakat maka metode penelitian yang digunakan yakni penelitian hukum empiris.

Pada umumnya penelitian hukum mempunyai dua tipe yaitu penelitian tipe yuridis normatif dan yuridis empiris. Pendekatan yuridis normatif tersebut mengacu kepada norma-norma hukum yang terdapat dalam Peraturan Perundang-Undangan serta norma hukum yang ada dalam masyarakat. Sedangkan pendekatan yuridis empiris atau sosiologis hukum adalah pendekatan yang digunakan untuk melihat aspek-aspek hukum dalam interaksi sosial didalam masyarakat dan berfungsi sebagai penunjang untuk mengidentifikasi dan mengklarifikasi temuan bahan non hukum bagi keperluan penelitian atau penulisan hukum. ${ }^{6}$

\section{Pembahasan Dan Latar Belakang Terjadinya Illegal Logging Di Kawasan Hutan Lindung Paya Rebol}

Secara umum bentuk tindak pidana illegal logging di Kawasan Hutan Lindung Paya Rebol. Saat ini masih terjadi kegiatan perambahan yang berupa penebangan liar, dan pengrusakan hutan dengan mengalih fungsikan hutan menjadi lahan perkebunan hortikultura (budidaya tanaman) yang dilakukan oleh masyarakat yang berada di sekitar kawasan hutan lindung tersebut. Sebagian besarnya masyarakat menggunakan lahan hutan kemudian mengelolanya untuk tempat kegiatan bercocok tanam dengan varietas tanaman kentang, kubis, bawang, dan tanaman hortikultura lainya. Menurut keterangan bapak Kepala kampung Nosar Baru yang juga memiliki lahan perkebunan yang berada dalam kawasan hutan lindung tersebut, bahwa mereka tidak mengetahui lahan yang sudah mereka garap tersebut masuk kedalam kawasan hutan lindung, karena memang sebelumnya tidak ada pemberitahuan secara resmi dari pemerintah bahwa kawasan hutan tersebut adalah kawasan hutan lindung atau tidak, dan tidak ada tapal batas yang jelas apakah kawasan hutan tersebut merupakan kawasan hutan hak milik hukum adat setempat atau kawasan tersebut merupakan hutan konservasi, hutan produksi atau jenis hutan lainya. $^{7}$

Kegitan perambahan hutan lindung Paya Rebol dengan tanpa izin tersebut, sudah belangsung sejak tahun 1973 yang dilakukan oleh masyarakat hukum adat setempat. Hal

5 'Publikasi Statistik Direktorat Jendral Planologi Kehutanan Dan Tata Lingkungan, Kementrian Lingkungan Hidup Dan Kehutanan 2015.'

6 Zainudin Ali, Metode Penelitian Hukum (Sinar Grafika 2014), hlm. 105-107.

7 'Wawancara Dengan Bapak Kepala Desa Nosar Baru. Pada Tanggal 3 Desember 2017'. 
tersebut terjadi karena pada umumnya di kalangan masyarakat hukum adat setempat, jika membuka dan kemudian mengolah suatu tempat yang berada dalam kawasan hutan untuk dijadikan lahan bercocok tanam, maka lahan tersebut sudah sah secara hukum adat menjadi hak mililiknya,dengan syarat lahan tersebut sebelumnya tidak pernah dimiliki oleh siapapun.Sesuai dengan amanah Undang-undang No 18 Tahun 2013 Tentang Pencegahan dan Pemberantasan Perusakan Hutan, yang berwenang mengelola kawasan hutan adalah Pemerintah dan Pemerintah Daerah, namun Pemerintah dapat melimpahkan penyelenggaraan pengelolaan hutan kepada BUMN bidang kehutanan. Untuk itu dijelaskan lebih lanjut dalam ketentuan Peraturan Menteri Kehutanan Republik Indonesia Nomor :P.47/MENHUT-II/2013. Tentang Pedoman, Kriteria dan Setandar Pemanfaatan Hutan di wilayah tertentu pada kesatuan pengelolaan hutan lindung dan kesatuan pengelolaan hutan produksi. Dalam pasal 5 ayat (2) huruf a dan huruf b kriteria pihak ketiga yang dapat memanfaatkan hutan tersebut adalah

1. Masyarakat setempat

2. BUMN, BUMD, BUMS, Koperasi, Usaha Mikro Kecil Menengah (UMKM).

Untuk memperoleh hasil dan jasa hutan secara optimal adil dan lestari bagi kesejahteraan masyarakat, hutan harus dimaanfaatkan secara optimal dengan pengkalisifikasian pemafaantan hutan sebagai berikut

1. Pemanfaatan kawasan

2. Pemanfaatan jasa lingkungan

3. Pemanfaatan hasil hutan kayu dan bukan kayu

4. Pemungutan hasil hutan kayu dan bukan kayu

Pemanfaatan hutan di atas hanya bisa dilakukan pada kawasan hutan sebagai berikut:

1. Hutan konservasi kecuali pada cagar alam, zona rimba dan zona inti dalam taman nasional

2. Hutan lindung kecuali pada blok perlindungan

3. Hutan produksi

Dalam pemanfaatan hutan wajib disertai hutan yang meliputi:

1. IUPK ( Izin Usaha Pemanfaatan Kawasan )

2. IUPJL ( Izin Usaha Pemanfaatan Jasa Lingkungan )

3. IUPHHK( Izin Usaha Pemanfaatan Hasil Hutan Kayu )

4. IUPHHBK( Izin Usaha Pemanfaatan Hasil Hutan Bukan kayu)

5. IPHHK( Izin Pemungutan Hasil Hutan Kayu)

6. IPHHBK( Izin Pemungutan Hasil Hutan Bukan Kayu ). ${ }^{8}$

Faktor penyebab terjadinya tindak pidana ilegal logging di kawasan hutan lindung Paya Rebol

Terjadinya kegiatan penebangan liar dikawasan Hutan Lindung Paya Rebol didasari oleh beberapa permasalahan yang terjadi:

- Perbedaan pemahaman masyarakat terhadap kawasan hutan Umumnya masyarakat hukum adat setempat beranggapan bahwa, kawasan hutan

$\overline{8}$ 'Peraturan Menteri Kehutanan Republik Indonesia Nomor:P.47/MENHUT-II/2013. Tentang Pedoman, Kriteria Dan Setandar Pemanfaatan Hutan Di Wilayah Tertentu Pada Kesatuan Pengelolaan Hutan Lindung Dan Kesatuan Pengelolaan Hutan Produksi.' 
lindung Paya Rebol tersebut masih merupakan kawasan hutan yang berada di bawah pengawasan masyarakat adat setempat, sehingga mereka masih berani untuk melakukan perambahan dan pengalih fungsian kawasan hutan menjadi lahan untuk bercocok tanam dan mereka masih menganggap bahwa hutan tersebut sebagai warisan dari leluhur mereka terdahulu yang tidak boleh diganggu gugat oleh siapapun. ${ }^{9}$

- Masalah Ekonomi

Seiring dengan pesatnya pertumbuhan penduduk, kususnya di Kabupaten Bener meriah itu sendiri banyak lahan pertanian yang beralih fungsi menjadi permukiman. Hal ini berakibat pada semakin berkurangnya lapangan pekerjaan yang kemudian berdampak pada rendahnya tingkat prekonomian masyarakat pada daerah-daerah tertentu, di sisi lain masyarakat yang berasangkutan juga tidak mempunyai keahlian di bidang yang lain sehingga banyak masyarakat yang mencoba membuka kawasan hutan untuk dijadikan lahan bercocok tanam, demi memenuhi kebutuhan hidupnya. ${ }^{10}$

- Ketidak jelasan tapal batas pada kawasan hutan

Berdasarkan keterangan Kepala Kampung Nosar Baru, kecamatan Bener Kelipah, Pada umumnya mata pencarian masyarakat yang berada dekat kawasan hutan adalah bertani dan berkebun. Bagi warga masyarakat yang berdekatan dengan hutan memiliki kecenderungan untuk melakukan aktivitas pembukaan lahan perkebunan dengan melakukan penebangan hutan, umumnya masyarakat tersebut awam tentang kawasan hutan yang mereka rambah apakah itu hutan yang boleh di kelola atau tidak, karena pada awalnya di sekitar kawasan hutan tersebut tidak ada batas wilayah atau pamplet pengumuman kawasan hutan lindung atau kawasan hutan lainya. ${ }^{11}$

- Pola kemitraan yang dibangun oleh Pemerintah dengan Masyarakat

Selama ini masyarakat hanya diarahkan untuk menjaga dan memelihara hutan tanpa memikirkan bagaimana agar keberadaan hutan juga memiliki kontribusi dalam meningkatkan kesejahteraan masyarakat. Umumnya bagi masyarakat awam tidak tahu banyak soal jenis hutan baik itu hutan konservasi, hutan lindung, hutan adat dan jenis-jenis hutan lainya dan mereka tidak tahu hutan mana saja yang boleh dikelola atau digunakan untuk bercocok tanam.

- Budaya (adat/kebiasaan)

Yang dimaksud disini adalah kebiasaan-kebiasaan yang dilakukan oleh masyarakat dalam memperlakukan hutan yang berkonsentrasi pada terancamnya eksistensi hutan. Salah contoh di Bener Meriah seperti yang umumnya terjadi di kalangan masyarakat adat (Gayo),dikenal adanya sebuah peribahasa yang menjadi panutan masyarakat adat tersebut dalam membuka lahan baru yang berada dalam kawasan hutan disebut dengan istilah (Belang berpancang uten bertene) yang secara umum dapat diartikan apabila ada seseorang yang membuka lahan hutan dan kemudian mengelola suatu tempat atau kawasan hutan menjadi lahan bercocok tanam, maka lahan tersebut sudah sah secara hukum adat menjadi hak mililik orang tersebut dan tidak bisa diganggu gugat oleh siapapun. Kebanyakan kebiasaan tersebut sudah secara turun-temurun berlangsung pada masyarakat hukum adat, di Kabupaten Bener Meriah tradisi tersebut sudah sangat sulit untuk dirubah.

9 'Hasil Observasi Dan Wawancara Beberapa Masyarakat Hukum Adat Desa Bandar Jaya Dan Desa Nosar Baru, Kecamatan Bener Kelipah. Pada Tanggal 6 Desember 2017.'

10 'Wawancara Dengan Bapak Amri, Kepala Dinas Lingkungan Hidup Dan Kehutan Aceh, UPTD KPH Wilayah II Di Bener Meriah. Pada Tanggal 3 Desember 2017.' 
- Penegakan hukum

Penegakan hukum terhadap kegitan illegal logging sudah dilakukan oleh berbagai elemen aparat penegak hukum, dari semua pihak pejabat yang berwenang serta pihak Kepolisian dan istansi lainya baik itu ditingkat pusat maupun daerah.

- Aspek lemahnya pengawasan hutan

Selain adanya perambahan dikawasan hutan yang dialihfungsikan untuk lahan perkebunan masyarakat, fungsi kontrol yang masih lemah dalam menjawab konsistensi pelaksanaan Peraturan Perundang-undangan disektor kehutanan, baik dalam pelaksaan pencegahan maupun penegakan hukum atas berbagai pelanggaran yang terjadi. ${ }^{12}$

- Perkembangan teknologi

Perkembangan teknologi yang pesat mendorong kemampuan orang untuk mengkesploitasi hutan (illegal logging), baik itu di dalam kawasan hutan lindung atau hutan hutan lainya semakin mudah dilakukan, karena dengan berkembangnya teknologi untuk menebang pohon tidak memerlukan waktu yang lama sebab alatalatnya semakin canggih.

\section{Modus Terjadinya Tindak Pidana Illegal Logging Di Kawasan Hutan Lindung Paya Rebol}

Lebih lanjut dimensi modus kegitan illegal logging yang terjadi dikawasan hutan lindung Paya Rebol tersebut antara lain :

\section{Modus Operandi}

- Terkait masalah perizinan

Secara jelas izin pemanfaatan hutan lindung sangat dibatasi oleh Pemerintah yang diatur dalam Undang-undang No 18 Tahun 2013 ayat (9) dan (10) tentang pemanfaatan hutan adalah kegiatan untuk memanfaatkan kawasan, jasa lingkungan, hasil hutan kayu dan bukan kayu, serta memungut hasil hutan kayu bukan kayu secara optimal dan adil untuk kesejahteraan masyarakat dengan tetap menjaga kelestarianya.

- Merubah fungsi utama hutan lindung

Dalam hal ini masyarakat yang melakukan kegiatan pertanian yang berada di dalam kawasan hutan lindung Paya Rebol, dengan cara merambah dan mengrusak kawasan hutan serta menebang batang-batang pohon dan kemudian menumpuknya di sekitar lahan perkebunan yang berada dalam kawasan hutan tersebut, hingga merubah fungsi utama dari hutan lindung itu sendiri

- Membawa alat pemotong kayu

Dalam hal membawa alat-alat yang lazim digunakan untuk menebang, memotong atau membelah pohon di dalam kawasan hutan tanpa izin dari pihak pejabat yang berwenang.

- Lokasi perambahan hutan.

Berdasarkan data yang diperoleh dari Dinas Lingkungan Hidup dan Kehutanan Aceh. Pada titik koordinat antara E 96051'35,8' dan N 04047'34,5'. Masih terdapat kegiatan pengalih fungsian hutan menjadi lahan perkebunan .lokasi perambahan hutan yang dilakukan pelaku benar masuk dalam kawasan hutan lindung dengan titik koordinat antara E 96051'35,8'” dan N 04ㄴ7'34,5'. Dengan

12 'Hasil Observasi Dan Wawancara Beberapa Masyarakat Hukum Adat Desa Bandar Jaya Dan Desa Nosar Baru, Kecamatan Bener Kelipah. Pada Tanggal 6 Desember 2017.' (n 9). 
lahan seluas 6 (enam) ha. ${ }^{13}$

2. Modus Vevendi

- Adanya Oknum

Dalam masalah perambahan hutan ini yang menjadi pelaku pengrusakan hutan adalah masyarakat yang umumnya berada di sekitar kawasan hutan serta masyarakat pendatang yang berada diluar kampung Nosar Baru tersebut. Serta Berdasarkan kuitipan dari beberapa sumber media, Forum Masyarakat Peduli Lingkungan Bener Meriah (FMPLBM), menuding praktek illegal logging mulai marak terjadi sejak awal tahun 2013 yang melibatkan oknum pejabat daerah, pihak keamanan dan pengusaha holtikultura. Perambahan hutan ini berhubungan dengan adanya program daerah untuk penanaman kentang dan palawija. Juga disebutkan bahwa ada wacana investor dari Malaysia yang menjalin kerja sama dengan pihak pemerintah Bener Meriah sebagai pasar kentang dan palawija. ${ }^{14}$

\section{Proses Penerapan Sanksi Tindak Pidana Illegal Logging Di Kawasan Hutan Lindung Paya Rebol}

Upaya memberantas kegiatan illegal logging telah dilakukan tetapi belum memperlihatkan hasil yang maksimal karena masih lemahnya penegakan hukum yang dilakukan oleh Pemerintah indonesia. ${ }^{15}$ Beberapa tahapan proses tersebut diantaranya adalah :

- Investigasi polisi

Pada tahun 2014 sampai tahun 2015 telah ditindak lanjuti oleh Dinas Lingkungan Hidup dan kehutanan Aceh yang bekerja sama dengan pihak kepolisian dari Polres Bener Meriah, sesuai dengan jalur hukum yang sah dan Undang-undang Nomor18 tahun 2013 tentang Pencegahan dan Pemberantasan Perusakan hutan. Polisi melakukan beberapa penahanan terhadapm terduga yang melakukan penebangan liar, dan berhasil meneruskan kasus tersebut sampai ke pihak jaksa penuntut.

- Penuntut oleh jaksa

Dinas Lingkungan Hidup dan kehutanan Aceh. Telah melimpahkan beberapa kasus besar terkait kejahatan kehutanan yang terjadi di kawasan hutan lindung Paya Rebol. Untuk itu jaksa penuntut umum diperbolehkan menginvestigasi kasus perambahan dan pengrusakan hutan di kawasan hutan lindung tersebut.

- Proses pengadilan

Salah satu kasus yang saat itu masih berhak ditangani oleh wilayah Pengadilan Negeri Takengon berhasil melakukan penegakan hukum atas kasus perambahan dan perusakan hutan yang terjadi di kawasan hutan lindung Paya Rebol dengan Putusan Perkara Pidana dengan Nomor Register Perkara : 20/PID.SUS/2015/PN-TKN. Sesuai dengan penerapan sanksi pada kasus illegal logging tersebut, para pelaku dikenakan

13 Putusan Pengadilan Negeri Takengon, Perkara Pidana Nomor : 20/PID.SUS/2015/PN-TKN. hlm.13.

14 'Pemkab Bener Meriah Diduga Merambah Hutan' <https://m.merdeka.com/peristiwa/pemkabbener-meriah-dituding-rambah-hutan.html>.

15 Mengenai upaya pemberantasan tindak pidana illegal logging oleh pemerintah, lihat Winarno Budyatmojo, 'Penegakan Hukum Tindak Pidana Illegal Loging (Antara Harapan Dan Kenyataan)' (2013) 2 Yustisia Jurnal Hukum <https://jurnal.uns.ac.id/yustisia/article/view/10192>; Muh Askal Basir, 'Upaya Pemerintah Dalam Menangani Illegal Loging (Studi Pada UPTD Kehutanan Kecamatan Kulisusu Kabupaten Buton Utara)' (2016) 1 Kybernan: Jurnal Studi Kepemerintahan $38<$ https:// www.jurnal-umbuton.ac.id/index.php/Kybernan/article/view/171>; Josefhin Mareta, 'Tindak Pidana Illegal Logging Dalam Konsep Keamanan Nasional' [2016] Rechts Vinding; Muhammad Ashlam Tangngalangi, Hariadi Kartodihardjo and Iin Ichwandi, 'Analisis Kebijakan Pembentukan SPORC Dan Implementasinya Dalam Pemberantasan Illegal Loging Di Indonesia' [2014] Jurnal Analisis Kebijakan Kehutanan. 
dengan Pasal-Pasal sebagaimana diatur dalam Pasal 82 ayat (1) hurup c jo Pasal 12 hurf c UU No 18 tahun 2013 tentang Pencegahan dan Pemberantasan Perusakan Hutan jo Pasal 55 ayat (1) ke-KUHP.Yang sudah disebutkan dalam putusan pengadilan Negeri Takengon. ${ }^{16}$

\section{Upaya Mengatasi Illegal Logging}

Penanggulangan Illegal logging tetap harus diupayakan hingga kegiatan illegal logging berhenti sebelum habisnya sumber daya hutan dimana terdapat utunk Kawasan hutan tetapi tidak terdapat pohin-pohon didalamnya. Penanggulangan Ilegal Logging tetap harus dilakukan melalaui kombinasi dari upaya pencegahan(preventip), penanggulangan (represif),dan upaya monitoring (deteksi ).

1. Deteksi terhadap adanya kegiatan penebangan liar Dapat dilakukan dengan beberapa cara diantaranya:

- Deteksi dengan cara melakukan patroli kehutanan yang tersebar di beberapa titik kawasan hutan yang di anggap rawan terjadi perambahan hutan.

- Menerima dan menindaklanjuti adanya informasi yang diterima dari masyarakat

- Pemeriksaan dokument terkait kepemilikan lahan .izin usaha dan dokument laporan yang diterima setiap adanya laporan

2. Melakukan upaya pencegahan (preventif) untuk mencegah terjadinya tindak pidana illegal logging atau pembalakan liar. Upaya preventif merupakan tindakan yang berorientasi ke depan yang sifatnya strategis dan merupakan rencana aksi jangka panjang, namun harus dipandang sebagai tindakan yang mendesak yang harus dilakukan.Upaya pencegahan (preventif) tersebut dapat dilakukan dengan beberapa cara yakni melalui:

- Pemberdayaan masyarakat seperti pemberian akses terhadap pemanfaatan sumber daya hutan agar masyarakat dapat ikut menjaga hutan dan merasa memiliki, dan tidak hanya sekedar memanfaatkan saja, tapi dapat melindungi hutan dengan tidak merusaknya, dan termasuk pendekatan kepada pemerintah daerah untuk lebih bertanggung jawab terhadap kelestarian hutan yang bebanya tidak hanya dipikul oleh satu istansi pemerintah saja.

- Peningkatan dukungan sarana dan prasarana untuk menunjang profesionalisme SDM (sumber daya manusia).

- Pengembangan sosial ekonomi masyarakat seperti menciptakan lapangan pekerjaan atau pekerjaan dengan pendapatan yang melebihi upah yang dihasilkan dari merusak hutan atau menggunakan lahan untuk kegiatan penanaman hortikultura atau minimal seimbang dengan penghasilan yang didapat dari kegitaan illegal logging .

- Pengembangan program pemberdayaan masyarakat, seperti mengadakan kegiatan-kegiatan yang dapat meningkatkan prekonomian masyarakat, serta dapat memberikan dampak positif bagi masyarakat.

- Evaluasi dan review Peraturan Perundang-undangan serta relokasi fungsi kawasan hutan dengan lebih rasional.

- Penegasan penataan batas kawasan hutan, baik itu hutan lindung, hutan produksi atau jenis hutan lainya, agar masyarakat mengerti dengan jelas batasan-batasan hutan tersebut, walaupun tidak paham seluk beluknya tapi setidaknya tapal batas hutan tersebut memberikan rambu-rambu awal bagi

16 Undang-Undang No 18 Tahun 2013 Tentang Pencehagan dan Pemberantasan Perusakan Hutan. 
msyarakat awam untuk tidak melakukan perusakan hutan.

- Melakukan seleksi yang lebih ketat dalam pengangkatan pejabat yang nantinya akan mengurusi masalah kehutanan, sehingga meminimalisir terjadinya halhal yang dapat menciptakan peluang untuk akses terhadap perusakan hutan.

3. Melakukan upaya penaggulangan (refresif)

- Tindakan ini adalah tindakan penegakan hukum mulai dari penyelidikan, penydikian sampai ke pengadilan. Untukitu harus ada kesamaan persefsi antara masing-masing unsur penegakan hukum yaitu penyidik (Polri dan PPNS), jaksa penuntut dan hakim. Karena besarnya permasalahan illegal logging tindakan represif harus mampu menimbulkan efek jera sehingga pemeberian sanksi hukum harus tepat dan penerepan sanksi hukum juga harus maksimal agar dapat mengurangi tindakan kejahatan terhadap hutan tersebut.

- Melakukan pendekatan kepada masyarakat desa yang berada di sekitaran hutan dengan melakukan sosialisasi UU No 18 Tahun 2013 tentang Pencegahan dan Pemberantasan Perusakan Hutan, mengadakan patroli rutin dilapangan, memeriksa kendaraan yang keluar masuk hutan dengan membawa kayu.

- Melakukan penindakan langsung terhadap pelaku illegal logging. ${ }^{17}$

\section{Kesimpulan}

1. Secara umum bentuk tindak pidana illegal logging yang terjadi di kabupaten Bener Meriah tepatnya pada kawasan hutan lindung Paya Rebol.Yakni dengan melakukan penebangan dibekas lahan yang sudah dirambah sebelumnya, serta sebagianya masih membuka lahan baru dengan melakukan perusakan dan pengalih fungsian hutan lindung. Yang sebagian besar lahan perkebunan tersebut dialihfungsikan untuk lahan perkebunan hortikultura (budidaya tanaman) yang mendominasi tanaman masyarakat didalam kawasan hutan lindung tersebut.

2. Faktor-faktor penyebab terjadinya tindak pidana illegal logging demi memenuhi kebutuhan ekonomi masyarakat untuk keberlangsungan hidup sehari-hari. Tidak ada tapal batas yang jelas pada wilayah kawasan hutan khususnya hutan lindung, masih lemahnya perencanaan dan pengawasan hutan yang dilakukan oleh pihak yang terkait, kurangnya jumlah personil aparat pengawas hutan yang tidak sebanding dengan luas kawasan hutan yang harus diawasi dan kemitraan yang dibangun oleh pemerintah dengan masyarakat masih sangat kurang, kurangnya sosialisasi tentang kehutanan terhadap masyarakat hukum adat, sehingga terjadi kesalah pahaman masyarakat hukum adat setempat yang masih menganggap bahwa hutan lindung tersebut juga masih merupakan bagian dari wilayah hutan milik masyarakat hukum ada setempat dan mereka tetap mempercayai tradisi yang di bawa oleh leluhur nenek moyang mereka.

3. Upaya yang dilakukan oleh Pemerintah Daerah kabupaten Bener Meriah terkait Pencegahan dan pemberantasan Perusakan Hutan dan tindak pidana illegal logging di kawasan hutan lindung Paya Rebol yang ditangani oleh Dinas lingkungan Hidup dan Kehutanan UPTD wilayah III dan 11 Aceh dan bekerja sama dengan seluruh pihak terkait yakni dengan memberikan sosialisasi tentang betapa pentingnya untuk tidak merambah hutan dan merusak hutan serta perlunya menjaga lingkungan hidup, memaksimalkan pengawasan hutan dengan membentuk post polisi kehutanan di beberapa titik kawasan hutan yang dianggap sangat rawan

17 'Wawancara Dengan Bapak Syafrudin, Kasi Perlindungan, Pengamanan Hutan Dan Penegakan Hukum, Dinas Lingkungan Hidup Dan Kehutanan Aceh. Pada 17 Desember 2017.' 
terjadi perambahan hutan. Dan upaya penindakan langsung ditempat apabila ditemukan pelaku perambahan hutan (illegal logging) yang terbukti salah secara hukum. Serta dengan mengkombinasikan upaya-upaya pencegahan (preventif), penanggulangan (represif) dan upaya monitoring (deteksi).

4. Penerapan sanksi pidana terhadap kasus perambahan hutan lindung Paya Rebol menurut penulis sudah sesuai dengan dengan apa yang dimaksudkan di dalam ketentuan Undang-undang Nomor 18 tahun 2013 Tentang Pencegahan dan Pemberantasan Perusakan Hutan, dengan memberikan sanksi baik berupa pidana pokok maupun pidana tambahan, dengan tujuan memberikan efek jera terhadap pelaku dan umumnya terhadap masyarakat banyak. Namun tetap saja diluar peraturan tertulis tersebut masih ada aturan khusus yang berlaku disuatu daerah seperti aturan hukum adat yang juga tidak boleh dikesampingkan karena keberlakukanya juga bersifat mengikat bagi suatu masyarakat hukum adat yang tinggal dalam suatu tempat.

5. Modus kegiatan Illegal logging di kawasan hutan lindung

Perambahan hutan ini berhubungan dengan adanya program daerah untuk penanaman kentang dan palawija yang dijadikan sebagai penghasilan utama daerah. Juga disebutkan bahwa ada wacana investor dari Malaysia yang menjalin kerjasama dengan pihak Pemerintah Bener Meriah sebagai pasar kentang dan palawija. Oleh kerena hal tersebut banyak pihak, baik dari kalangan masyarakat biasa sampai pejabat, berlomba-lomba ingin menanam kentang, mengingat harga ketang yang cukup mahal karena langsung di ekspor. Oleh karena hal tersebut ada pihak-pihak pejabat yang memanfaatkan siatuasi, salahsatunya dengan menyalahgunakan kekuasaan mereka terutama dalam masalah perizinan untuk membuka lahan pada kawasan hutan lindung.

\section{DAFTAR KEPUSTAKAAN}

Ahmad M, 'Ekologi Berbasis Syariah: Analisis Wacana Kritis Pemikiran Mudhofir Abdullah' (2015) 13 JURNAL HUKUM ISLAM 57 <http://e-journal.iainpekalongan.ac.id/index. php/jhi/article/view/496>

Ahmad Redi, Hukum Sumber Daya Alam Dalam Sektor Kehutanan (Sinar Grafika 2014)

Ashlam Tangngalangi M, Kartodihardjo H and Ichwandi I, 'Analisis Kebijakan Pembentukan SPORC Dan Implementasinya Dalam Pemberantasan Illegal Loging Di Indonesia' [2014] Jurnal Analisis Kebijakan Kehutanan

Basir MA, 'Upaya Pemerintah Dalam Menangani Illegal Loging (Studi Pada UPTD Kehutanan Kecamatan Kulisusu Kabupaten Buton Utara)' (2016) 1 Kybernan: Jurnal Studi Kepemerintahan 38 <https://www.jurnal-umbuton.ac.id/index.php/Kybernan/ article/view/171>

Budyatmojo W, 'Penegakan Hukum Tindak Pidana Illegal Loging (Antara Harapan Dan Kenyataan)’ (2013) 2 Yustisia Jurnal Hukum <https://jurnal.uns.ac.id/yustisia/ article/view/10192>

'Hasil Observasi Dan Wawancara Beberapa Masyarakat Hukum Adat Desa Bandar Jaya Dan Desa Nosar Baru, Kecamatan Bener Kelipah. Pada Tanggal 6 Desember 2017.'

Juwita DR, 'Fiqh Lingkungan Hidup Dalam Perspektif Islam' [2017] El-Wasathuya: Jurnal Studi Agama 
Mareta J, 'Tindak Pidana Illegal Logging Dalam Konsep Keamanan Nasional' [2016] Rechts Vinding

Ninik Suparni, Pelestarian, Pengelolaan, Dan Peneggakan Hukum Lingkungan (Sinar Grafika 1994)

'Pemkab Bener Meriah Diduga Merambah Hutan' < https://m.merdeka.com/peristiwa/ pemkab-bener-meriah-dituding-rambah-hutan.html>

'Peraturan Menteri Kehutanan Republik Indonesia Nomor:P.47/MENHUT-II/2013. Tentang Pedoman, Kriteria Dan Setandar Pemanfaatan Hutan Di Wilayah Tertentu Pada Kesatuan Pengelolaan Hutan Lindung Dan Kesatuan Pengelolaan Hutan Produksi.'

'Publikasi Statistik Direktorat Jendral Planologi Kehutanan Dan Tata Lingkungan, Kementrian Lingkungan Hidup Dan Kehutanan 2015.'

'Undang-Undang-Nomor 18 Tahun 2013' (Http://Www.Hukumonline.Com/UndangUndang-Nomor 18 Tahun 2013/di akses tanggal 12 Maret 2017.11.23.) <http://www. hukumonline.com> accessed 12 March 2017

'Wawancara Dengan Bapak Amri, Kepala Dinas Lingkungan Hidup Dan Kehutan Aceh, UPTD KPH Wilayah II Di Bener Meriah. Pada Tanggal 3 Desember 2017.'

'Wawancara Dengan Bapak Kepala Desa Nosar Baru. Pada Tanggal 3 Desember 2017'

'Wawancara Dengan Bapak Kepala Desa Nosar Baru Kecamatan Bener Kelipah. Pada Tanggal 3 Desember 2017.'

'Wawancara Dengan Bapak Syafrudin, Kasi Perlindungan, Pengamanan Hutan Dan Penegakan Hukum, Dinas Lingkungan Hidup Dan Kehutanan Aceh. Pada 17 Desember 2017.'

Zainudin Ali, Metode Penelitian Hukum (Sinar Grafika 2014)

Zuhdi MH, 'Paradigma Fiqh Al-Bi'ah Berbasis Kecerdasan Naturalis: Tawaran Hukum Islam Terhadap Krisis Ekologi' [2017] AL-'ADALAH

Putusan Pengadilan Negeri Takengon, Perkara Pidana Nomor : 20/PID.SUS/2015/PNTKN. hlm.13.

Undang-Undang No 18 Tahun 2013 Tentang Pencehagan dan Pemberantasan Perusakan Hutan. 